\title{
GROWTH DECOMPOSITION IN THE Socialist CZECH ECONOMY
}

\author{
Marek Soukup ${ }^{1}$, Libor Žídek ${ }^{2}$
}

\begin{abstract}
Economic growth in centrally planned economies was declining with the duration of these economic systems. There were multiple reasons for this development. Deeper insight can be provided by dividing economic growth into extensive and intensive parts. The goal of this article is to estimate the share of extensive and intensive aspects of economic growth in the socialist Czech economy in the last two decades of the socialist era (1970-1989). We conclude that the extensive growth in this period stood for approximately $55 \%$ of the overall growth. This figure is broadly twice higher than comparative numbers for the post-communist period.
\end{abstract}

\section{Keywords}

Centrally Planned Economy, Economic Growth, Extensive Growth, Intensive Growth, Czech Republic

\section{Introduction}

Economic outcomes of socialist economies were worsening during the centrally planned era. Economic historians provide multiple explanations for this development. One of the pivotal aspects of the socialist economies was the character of economic growth. Generally, we can distinguish between extensive and intensive aspects of growth. The former is caused by increasing the amount of production factors (labour, capital etc.) into the economic system. Intensive economic growth is, on the contrary, generated by more efficient use of the sources already used in the system - in other words by increasing productivity of production factors. Overall economic growth is always caused by both of these aspects, but the difference lies in the share of the extensive and intensive parts. Socialist economies generally inclined to extensive patterns of economic growth. As time progressed, the availability of new sources in the system was diminishing, which contributed to a declining pace of economic growth. In reaction, the socialist planners set

\footnotetext{
${ }^{1}$ The University of Edinburgh, South Bridge, Edinburgh, EH8 9YL, Great Britain. E-mail: soukup.mk@gmail.com.

${ }^{2}$ Masaryk University, Faculty of Economics and Administration, Lipová 507/41a, 60200 Brno, Czech Republic. E-mail: Libor.Zidek@econ.muni.cz.
} 
ambitious goals regarding productivity increases, which were not accomplished. The goal of this article is to estimate the share of extensive and intensive aspects of economic growth in the socialist Czech economy in the last two decades of the socialist era (1970-1989).

There is a plethora of literature dedicated to measurement of economic growth and its structure. A significant portion of this research focuses on the centers of economic activity, such as China (Zhu, 2012) or the US (Shackleton, 2013). Others concentrate on East Asia in general (Felipe, 1999) or other developing countries. However, it seems that scientists have been less concerned with Eastern Europe and the post-Soviet area. Among studies which are the closest to out area of interest, are Arazmuradov, Martini, Scotti (2014) who studied total factor productivity (TFP) in the successive countries of the USSR. The same has been done, with more or less significant focus on a certain part of the economy, for instance by Zhang (1997) or Iradian (2007). A study researching into the TFP in the Czech Republic was conducted by Djankov, Hoekman (2000). Nevertheless, our study aims to examine the growth of a particular country during the socialist era, that is, the composition of growth in a centrally planned economy. For all we know, this has not been done yet.

The cornerstone of our inquiry is the Solow model of economic growth. However, unlike many other studies, we do not estimate the model econometrically. Instead, we use the model to derive two indices - one for extensive, and the other for intensive growth. These two indices break the overall growth into two parts and represent the percentage share of each of them. The methodology is based on the seminal paper by Solow (1956), as well as the classic books by Barro, Sala-i-Martin (2004) and Acemoglu (2009). Moreover, the derivation of the indices follows Ramík (1986), Mihola (2007), Hájek, Mihola (2009) and Mihola, Wawrosz (2014).

Research into the economies of the former Eastern Bloc suffers from a shortage of data. The economists from the University of Economics in Prague tried to fill the gap by estimating GDP and its composition. This has been done for the period between the years 1970 and 1990 (the data for the preceding decades unfortunately do not exist at all). Moreover, these data describe only the economy of the Czech Socialist Republic - one of the two parts of the former state of Czechoslovakia.

The paper is organised as follows. We analyse the characteristics of economic growth during the socialist era in section II. The following section is devoted to the formal description of the model. The fourth to data and specific settings of the model for the socialist Czech economy. Our results are examined in the fifth section.

\section{Characteristics of economic growth in the socialist era}

The communists took control of Czechoslovakia in 1948. They immediately introduced a centrally planned economic system. The system was based on hierarchical organisation of the whole production and on nationalisation. Economic results in the first years seemed to be positive and the economy achieved high rates of economic growth - see Figure 1. However, the trend in the next decades was declining and average growth of social product in the 1980 s was just $1.8 \%$ per year. $^{3}$

\footnotetext{
${ }^{3}$ Socialist economies officially used a Net Material Product (Social Product) indicator. The main difference in comparison to GDP was that it included material productions and excluded most of the services.
} 
Figure 1: Changes in social product 1950-1989 in \%

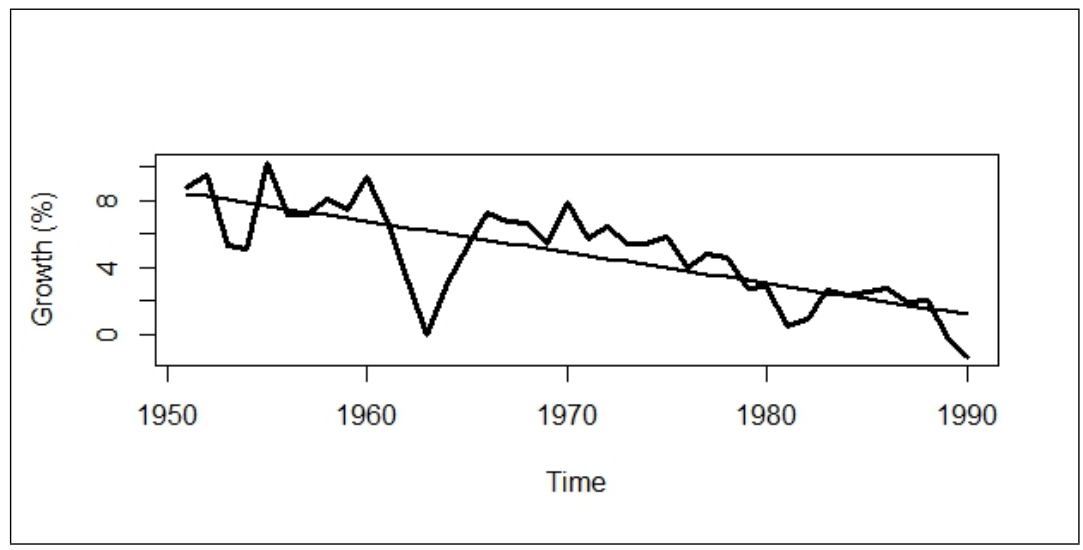

Source: Statistické ročenky Československé socialistické republiky 1971-1990

There are multiple reasons to blame for this development. As a pivotal element, low efficiency of the overall centrally planned system and low efficiency of using resources is often mentioned. Efficiency on the global level can be approximately expressed by dividing economic growth into its extensive and intensive parts. This division broadly expresses twofold reasons for economic growth (in practice economic growth is always comprised of the mix of both). The reasons for extensive part of economic growth lie in adding more sources (labour force, investment or land) into the production process. On the contrary, increasing efficiency of the use of the sources is expressed in the intensive aspects of economic growth (e.g. Berend, 2009).

All centrally planned economies were inherently prone to grow extensively rather than intensively (e.g. Adam, 1995). There were relatively many free sources at the beginning of the communist era and they contributed to high economic growth. But these new sources were naturally diminishing as time progressed and so was economic growth. The reasons for the prevalence of the extensive character of growth lay in the very basis of the functioning of the system - it lacked competitive pressure (Roemer, 1994) typical for the capitalist system; the structure of the economy was monopolistic (e.g. Lavigne, 1999). The system did not support economic initiative partly because of the state ownership, but on the contrary, in practice it encouraged companies to seek inputs maximisation and outputs minimisation (Knaack, 1984). In addition, the overall planning process was highly inefficient as well. There were multiple proofs that the economic growth had an extensive character. First and foremost, there was an omnipresent and lasting shortage of everything from raw materials, via semi-manufactured goods and energies up to labour force (e.g. Kornai, 1980). At the same time, although the economy did not have any spare capacities (e.g. Holman, 2000), many "idle goods" were produced (nobody wanted to purchase them - they were produced just to accomplish the plan) (Myant, 2003). The rate of energy and raw materials per unit of production was in comparison to market economies very high - by the end of the 1980s, the consumption of energy per a percent of GDP was 
eight times higher than the average in European countries (Berend, 2009). Adversely, comparative kilogram prices of the productions were very low - Czechoslovak producers received fewer dollars than western producers for one kilogram of production (e.g. Zeman, 1990). The indirect proof of prevailing extensive growth was in the catastrophic state of the environment that was devastated by extensive use of sources.

This extensive character of economic growth was well known to economic planners in the centrally planned systems (e.g. Hába, 1988; Průcha, 1988; Malý and Herc, 1988) as well as to experts abroad (e.g. Nuti, 1981). It was considered to be one of the main drawbacks of the socialist economic system. The authors' opinions varied on estimating the period by which the sources of extensive growth were already exhausted. For example, a textbook of central planning from 1988 mentioned that the extensive sources were already nearly totally exhausted in the first half of the 1960s (Průcha, 1988). Adam dated this state to the 1970s (Adam, 1995) and Hába to the early 1980s (Hába, 1988).

The communist economists and politicians struggled to increase the intensive share of economic growth (e.g. Hrnčîr, 1987; Průcha, 1988). Nykryn in 1988 wrote that: "the basic strategy of the economic development of the Czechoslovak Socialist Republic is aimed at detaching itself from the largely extensive development, the promotion of qualitatively new intensive tendencies..." (Nykryn, 1988, 329). The communist politicians often set ambitious goals in this respect. These efforts were expressed among others in economic reforms $(1958,1968,1980)$. They sought to increase independence of the state-owned companies of the economic centre in hope that these companies would increase their efficiency. But these expectations were not lived up to. The goals for increasing efficiency were ambitious for respective five-year plans too - see Table 1 .

The regime for this reason supported high level of investment and spending into research and development but these sources were not used in an efficient way either (Berend, 2009). The extensive character of economic growth lasted regardless of the effort of the centre (e.g. Swain, 1998) and eventually led to stagnation of economic growth (Adam, 1995). Průcha for example wrote: "In terms of strategic goals of intensification of the economy, however, the seventh five-year plan [1981-85] did not become a qualitative breakthrough". And the main goal for the eight five-year plan was again: "transition of the economy to an intensive type of development" (Průcha, 1988, 69). These failures contributed to the economy's lagging behind the developed countries.

In the following sections were estimate the proportions of extensive and intensive parts of growth in socialist Czech economy.

\section{The model}

For the basic computation of the ratio of intensive and extensive growth, we use the basic Solow model in the form:

$$
Y_{t}=A_{t} F\left(K_{t}, L_{t}\right)
$$

where $Y_{t}$ stands for aggregate product, $A_{t}$ for total factor productivity $(T F P), F($.$) for$ production function and $K_{t}$ and $L_{t}$ for capital and labour. 
The same is true for values in any other time period ${ }^{4}$ (for discrete time) or every moment of time (for continuous time). By dividing the equation for time $t$ by the same equation with lagged values, we get the following relationship:

$$
\frac{Y_{t}}{Y_{t-1}}=\frac{A_{t}}{A_{t-1}} \frac{F\left(K_{t}, L_{t}\right)}{F\left(K_{t-1}, L_{t-1}\right)}
$$

Denote $I(Y)=\frac{Y_{t}}{Y_{t-1}}, I(A)=\frac{A_{t}}{A_{t-1}}$ and $I(F)=\frac{F\left(K_{t}, L_{t}\right)}{F\left(K_{t-1}, L_{t-1}\right)}$ and take logarithms of the above expression to get:

$$
\ln I(Y)=\ln I(A)+\ln I(F(K, L))
$$

which is the main equation of interest. From the Solow setting, it follows that the share of growth explicable by $F(K, L)$, that this, by the sheer amounts of production factors employed in the production process, is called extensive growth. The rest, which is called intensive growth, is in Solow terms interpreted as technological level of the particular country. In other words, how the variable $A$ is supposed to measure how effectively the production factors are being transformed into the final product.

However, it is necessary to make an important note right at the outset. The interpretation of $A$ (or $T F P$ ) as a technological level stems solely from the assumptions of the very commonly used Solow model. In fact, the so-called intensive growth actually represents what we cannot explain by the employment of capital and labour, and therefore can comprise much more that technology (which is difficult to measure). As Abramovitz (1956) put it, TFP is the measure of our ignorance. Nevertheless, we will be using the term 'intensive growth' in due course.

Now we can define the parameters of our ultimate interest. Let the parameter of extensity be:

$$
e=\frac{\ln I(F(K, L))}{|\ln I(A)|+|\ln I(F(K, L))|}
$$

and the parameter of intensity:

$$
i=\frac{\ln I(A)}{|\ln I(A)|+|\ln I(F(K, L))|}
$$

By definition, it must always hold that:

$$
|e|+|i|=1
$$

because these parameters decompose the overall growth into two parts. This also means that the values $e$ and $i$ are unit-free. Therefore, we have defined the parameters which will allow us to determine the composition of economic growth.

${ }^{4} Y_{t-j}=A_{t-j} F\left(K_{t-j}, L_{t-j}\right), j \in R$ 


\section{Data and model specification}

\section{Dataset}

The rather simple methodology introduced above will be applied to a unique dataset developed by economists and statisticians from the University of Economics in Prague (KEST 2018). This dataset comprises the yearly time series estimates of Czech GDP between the years 1970 and 1990 that was created using ESA 2010 methodology. The uniqueness of these data lies in the fact that the macroeconomic time series of the postcommunist countries usually start (at best) in 1990, that this, after the totalitarian regime was overthrown. For detailed methodology of estimating the data, see Sixta, Vltavská, Fischer (2013) and Sixta et al. (2016).

For our purposes, labour, capital and GDP are of interest. We used the indicator of employment in the economy as proxy for labour and gross capital formation for capital. GDP is real. All data originate in the above-mentioned dataset. The standardised variables are depicted in Figure 2.

\section{Figure 2: GDP, Labour, Capital (standardised)}

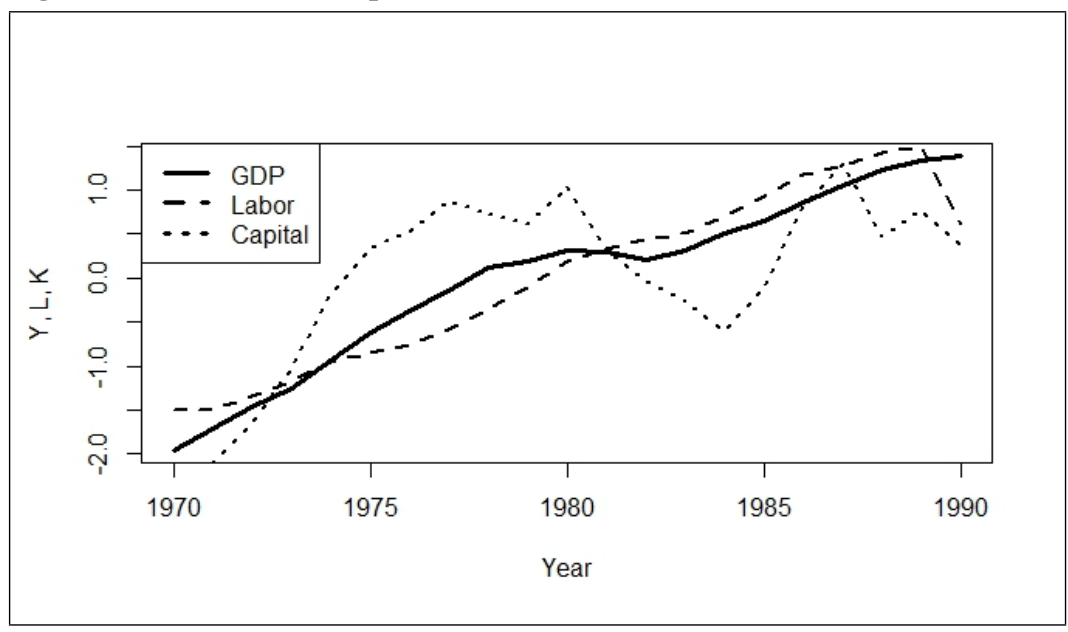

Source: Authors

The last variable we need is the Total Factor Productivity. Since all the other necessary variables from equation (1) are known, we get TFP simply from:

$$
A_{t}=Y_{t} / F\left(K_{t}, L_{t}\right)
$$

\section{Specific model}

Now we have to define the functional form of $F\left(K_{t}, L_{t}\right)$. In this paper, we use the standard neoclassical (Cobb-Douglass) production function in the form:

$$
F\left(K_{t}, L_{t}\right)=K_{t}^{\alpha} L_{t}^{1-\alpha}
$$


where $\alpha$ is the capital income share and $1-\alpha$ the labour income share. Taking the ratio of compensation of employees and the total GDP and taking the average over the whole considered time, we get $1-\alpha=0.45$ and therefore $\alpha=0.55$.

Now we can rewrite the previous general formulas in their specific form:

Parameter of extensity:

$$
e_{t}=\frac{\ln \left(K_{t}^{0.55} L_{t}^{0.45} / K_{t-1}^{0.55} L_{t-1}^{0.45}\right)}{\left|\ln A_{t} / A_{t-1}\right|+\left|\ln \left(K_{t}^{0.55} L_{t}^{0.45} / K_{t-1}^{0.55} L_{t-1}^{0.45}\right)\right|}
$$

Parameter of intensity:

$$
i_{t}=\frac{\ln A_{t} / A_{t-1}}{\left|\ln A_{t} / A_{t-1}\right|+\left|\ln \left(K_{t}^{0.55} L_{t}^{0.45} / K_{t-1}^{0.55} L_{t-1}^{0.45}\right)\right|}
$$

\section{Results}

The computed parameters of intensity and extensity are depicted in Figure 3.

Figure 3: Extensity and intensity parameters

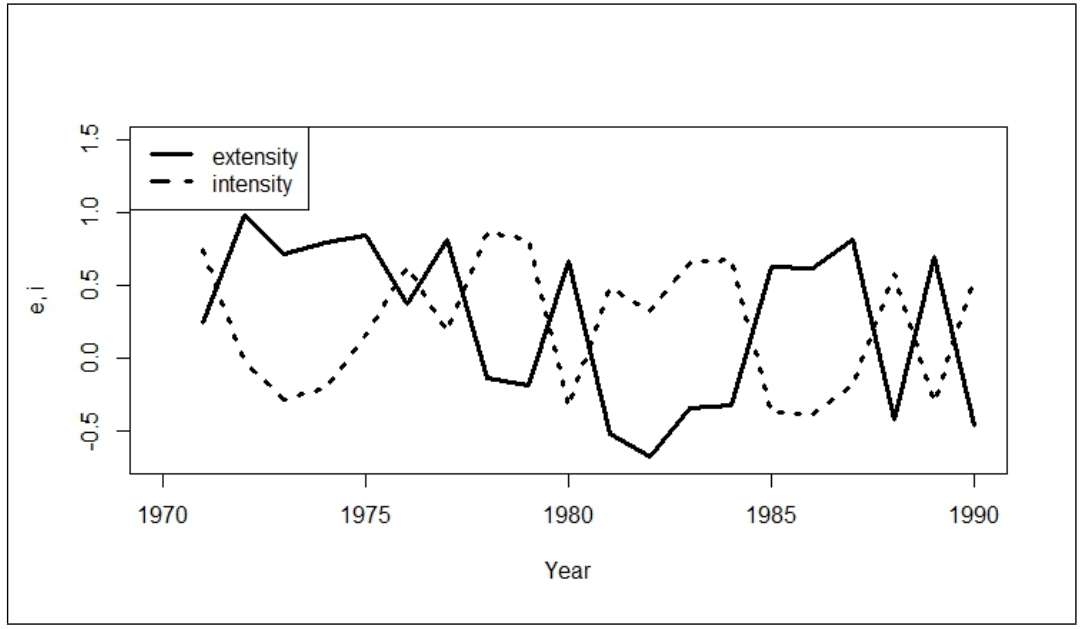

Source: Authors

Figure 4 captures these shares. Every bar of this plot is of height $=1$, representing the whole change in growth in the particular year. Each column is then divided between the extensive and intensive growth. 
Figure 4: Growth composition

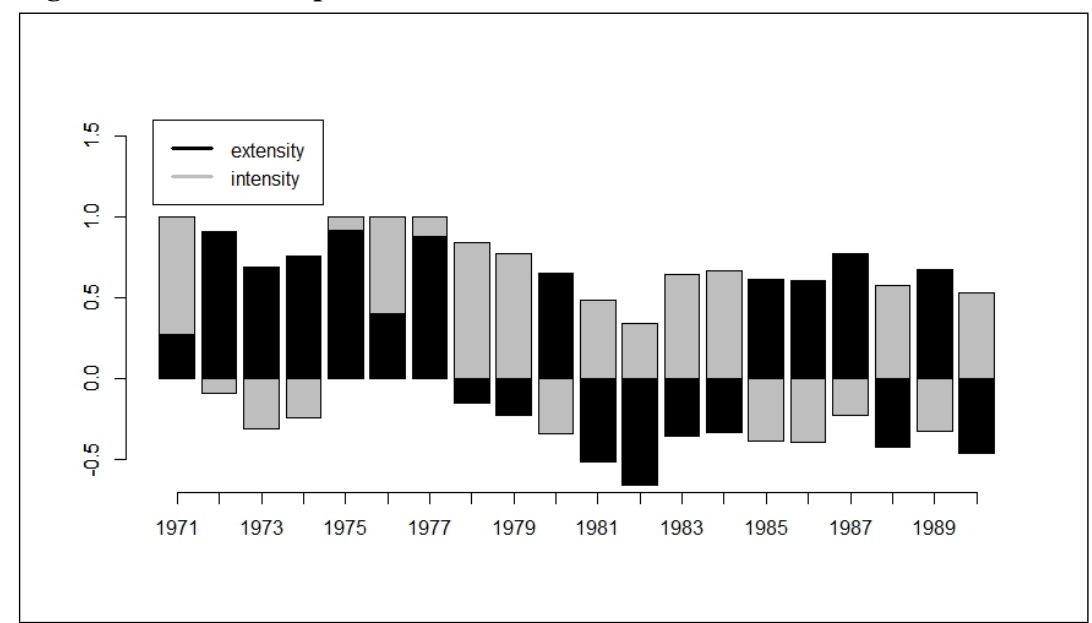

Source: Authors

Table 1 summarises the numerical characteristics of the data and results. The first and third line also contain the five-year plans set by the government of the former Czech Socialist Republic.

Table 1: Summary of the data and results (with five-year plans)

\begin{tabular}{|l|c|c|c|c|c|}
\hline Growth rates (\%) & $\mathbf{1 9 7 1 - 1 9 7 5}$ & $\mathbf{1 9 7 6 - 1 9 8 0}$ & $\mathbf{1 9 8 1 - 1 9 8 5}$ & $\mathbf{1 9 8 6 - 1 9 9 0}$ & All periods average \\
\hline GDP & 4.94 & 2.81 & 0.93 & 1.91 & 2.65 \\
\hline GDP plan & 5 & 5 & $1.5-2.1$ & 3.2 & \\
\hline Labour & 0.48 & 0.74 & 0.52 & -0.21 & 0.39 \\
\hline Labour productivity & 4.44 & 2.06 & 0.40 & 2.13 & 2.26 \\
\hline Labour prod. plan & 4.75 & 4.55 & $1.4-2$ & 2.9 & \\
\hline Capital & 9.69 & 1.98 & -3.02 & 1.81 & 2.61 \\
\hline TFP & -0.41 & 1.41 & 2.55 & 1.33 & 1.22 \\
\hline Shares (\%)* & & & & & \\
\hline Extensity & 65.96 & 58.89 & 51.18 & 47.63 & 56.44 \\
\hline Intensity & 34.04 & 41.11 & 48.82 & 52.37 & 43.56 \\
\hline
\end{tabular}

* - the overall shares are computed from absolute values.

Source: Authors; Zákon č. 115/1971 Sb.; 70/1976 Sb.; 125/1981 Sb.; č. 87/1986 
We can see from the results that the overall growth in the examined period was driven mainly by its extensive part -56.44 vs 43.56 on average. This confirms the common view that centrally planned or socialist economies suffer from lack of technological development and therefore economic growth is caused by employing more production factors. Note that both the data in Table 1 and the extensity share in Figure 3 roughly copy the pattern of investment into capital as shown in Figure 2. This supports the expectation that the pace of capital accumulation (an extensive factor) is the main driving force of changes in economic growth. After a boom at the beginning of the examined period came a sharp decline in the 1980's. It modestly increased afterwards, but did not reach the previous peak.

In Table 1, the real results are confronted with the plans of the regime. The only result which neared the five-year plan's goals was the first plan. This was due to a massive investment of the reserves accumulated in late 60's as a part of an attempt at an economic reform (Šik's reform). In the second five-year plan, the sources for investment were depleting and their depletion led to the instability and decline of the early 1980's. Towards the end of the communist era, the planners managed to stabilise the situation and even achieved relative growth, but it was too late already.

It can be found as surprising, though, that the share of extensive growth may have been lower than expected. The Solow model assumes that At is equal to the level of technology at given time. The productivity of labour is given by:

$$
Y_{t} / L_{t}=A_{t} k_{t}^{\alpha}
$$

and the second term, capital per capita, is almost constant (var $<0.001$ ). This would suggest that majority of growth in labour productivity, as well as the intensity parameter, is due to technological change (see for example Acemoglu, 2009: 28 and Barro, Sala-iMartin, 2004: 24 for more details). Ultimately, this would mean that nearly half of the growth was caused by technological change, which seems unlikely in a centrally planned economy.

However, as has been said above, intensity comprises simply everything that is not included in extensity. For instance, in a case of a small economy, which the Czech Republic definitely was, external factors would be considerably influential. For our case, these could be the economic shape of the Soviet Union, which is not taken into account in this study. Therefore, a comparison with another country or a different period of time can provide us with a hint whether the extensity in our data is excessive or not. Hájek and Mihola (2009) originally used this methodology for examining growth in the Czech economy between the years 1995 and 2007, when the economy already worked according to the capitalist model. Their findings show that the share of extensity in the given period was between 20 and 25 percent. The fact that several decades earlier, this share had been twice as big suggests that the Czech economy underwent a significant change.

We find one more detail rather surprising. Usually, the parameter $\alpha$ is calibrated as $1 / 3$, which represents the income share of capital (Acemoglu, 2009: 57). Given the fact that this number is derived from the state of affairs in capitalist economies, one would expect this number to be lower in a socialist economy. However, in our data, the division of income between the factors is roughly equal. A possible explanation is that the owners 
of capital were not actual capitalists, but the state, whose government was formed by the totalitarian communist regime. Therefore, a significant share of the income flowed to the state as the only capital owner. However, the income in fact belonged to the most prominent representatives of the regime. Moreover, this result can be attributed to the structure of the economy, which was based on heavy industry.

\section{Conclusion}

The socialist economies were characterised by extensive economic growth. Our article directly examined the character of economic growth in the Czech Socialist Republic during the last two decades of its existence. As a method, two complementary indices computed from the Solow model were used. They divide the overall growth into an extensive part, that is, growth caused by adding more production factors, and an intensive part, the core of which lies in the more effective use of the existing resources.

We can conclude the following: First, the extensive growth in this period stood for approximately $55 \%$ of the overall growth. The labour force was increasing steadily, unlike the capital accumulation, which underwent booms and busts. Regarding the intensive part, its share was modestly increasing during the period. Nevertheless, this increase cannot be deemed considerable taking the later development into account. After the changes in 1989, the share of extensive growth fell under 1/3.

Second, comparing the achieved growth rates with the goals set by the planners, we can see that these goals were never achieved. Moreover, the situation was worsening as time proceeded, which undoubtedly contributed to the ultimate collapse of the communist regime in the country.

In further research, we suggest examining the spatial and time comparison. That is, to compare the results obtained in this paper with development in a comparable, non-centrally planned Western economy. It could also be fruitful to lengthen the time period considered in order to estimate the extent of the break which the economy underwent after 1989. However, this involves the necessity to overcome several serious obstacles, which is why these questions have not been addressed in this paper.

\section{Acknowledgements}

This work was supported by the Grant Agency of the Czech Republic, GAČR Grant 20-23131S - Transformation of the Czech business: socialist enterprises in the market economy.

\section{References}

Abramovitz, M. (1956). Resource and output trends in the United States since 1870. Resource and output trends in the United States since 1870. NBER. 1-23.

Acemoglu, D. (2009). Modern economic growth. VoxEU. org 27.

Adam, J. (1995). Why did the Socialist System Collapsed in Central and Eastern Europe?. Houndhills: MacMillan Press. 
Arazmuradov, A., Martini, G., Scotti, D. (2014). Determinants of total factor productivity in former Soviet Union economies: A stochastic frontier approach. Economic Systems, March, 38(1), 115-135.

Barro, R. J., Sala-I-Martin X. (2004). Economic Growth. Massachusetts: MIT Press.

Berend, I. T. (2009). From the Soviet Bloc to the European Union. Cambridge University Press.

Djankov, S., Hoekman, B. (2000). Foreign investment and productivity growth in Czech enterprises. The World Bank Economic Review, 14(1), 49-64.

Hába, Z. et al. (1988). Politická ekonomie: stručný základ. Prague: Státní pedagogické nakladatelství, 1st edition.

Felipe, J. (1999). Total factor productivity growth in East Asia: A critical survey. The Journal of Development Studies, 34(4), 1-41.

Hájek, M., Mihola, J. (2009). Analysis of total factor productivity contribution to economic growth of the Czech Republic. Politická ekonomie, 57(6), 740-753.

Holman, R. (2000). Transformace české ekonomiky. Praha: Centrum pro ekonomiku a politiku.

Hrnčîř, M. (1987). Vnějši ekonomické vztahy a hospodářský mechanismus. Praha: Academia.

Iradian, M. G. (2007). Rapid growth in transition economies: Growth-accounting approach. International Monetary Fund Working Papers, Working Paper No. 07/164.

KEST (Katedra ekonomické statistiky) (2018). Odhady hrubého domácího produktu České republiky za roky 1970-1989 v ESA 2010; [online], Retrieved February 15, 2019, from https://kest.vse.cz/odhady-hrubeho-domaciho-produktu-ceske-republiky-zaroky-1970-1989-v-esa-2010/.

Knaack, R. (1984). Dynamic Comparative Economics: Lessons From Socialist Planning. In: Zimbalist A. (eds.). Comparative Economic Systems. Recent Economic Thought, vol 3. Springer, Dordrecht.

Kornai, J. (1980). Economics of Shortage. Amsterdam: North-Holland Publishing Company.

Lavigne, M. (1999). The Economics of Transition. St. Martin's Press Inc., New York, 1999, 2nd edition.

Malý, V., Herc, S. (1988). Příspěvek k pojetí systému plánovitého řízení v období intenzifikace. Politická ekonomie, 36(1), 17-28.

Mihola, J. (2007). Agregátní produkční funkce a podíl vlivu intenzivních faktorů. Statistika, No. 2.

Mihola, J., Wawrosz, P. (2014). Alternativní metoda měření extenzivních a intenzivních faktorů změny HDP a její aplikace na vývoj HDP USA a Číny. Politická ekonomie, 62(5), 583-604.

Myant, M. (2003). The rise and fall of Czech capitalism: economic development in the Czech Republic since 1989. Northampton, MA: Edward Elgar.

Nuti, D. M. (1981). Socialism on Earth. Cambridge Journal of Economics, 391-403.

Nykryn, J. (1988). Zahraniční obchod ČSSR. Praha: Nakladatelství Svoboda. 
Průcha, V. et al. (1988). Úvod do národohospodářského plánování. Praha: Nakladatelství technické literatury.

Ramík, J. (1986). Návrh souboru vybraných matematicky ověrených metod pro hodnocení ekonomické efektivnosti hospodářských celkủ. Ostrava: VÚROM.

Roemer, J. E. (1994). A Future for Socialism. London: Verso.

Sixta, J. et al. (2016). Czech GDP between 1970 and 1989 Based on ESA 2010. Statistika, $1,4-12$.

Sixta, J., Vltavská K., Fischer, J. (2013). Development of gross domestic product in the Czech republic and Slovakia between 1970 and 1989. Ekonomicky časopis (Journal of Economics), 61(6), 549-562.

Shackleton, R. (2013). Total factor productivity growth in historical perspective. Congressional Budget Office, Working paper No. 1.

Statistické ročenky Československé socialistické republiky. Praha: SNTL, 1971-1990.

Swain, N. J. (1998). The Visegrád Countries of Eastern Europe in European Economies Since the Second World War edited by Foley B. J., Macmillan Press Ltd, Houndmills.

Zákon č. 115/1971 Sb.: Zákon České národní rady o státním plánu rozvoje národního hospodářství České socialistické republiky na léta 1971-1975.

Zákon č. 70/1976 Sb.: Zákon České národní rady o státním plánu rozvoje národního hospodárství České socialistické republiky na léta 1976-1980.

Zákon č. 125/1981 Sb.: Zákon České národní rady o státním plánu rozvoje národního hospodářství České socialistické republiky na léta 1981-1985.

Zákon č. 87/1986 Sb.: Zákon České národní rady o státním plánu rozvoje národního hospodářství České socialistické republiky na léta 1986-1990.

Zeman, K. et al. (1990). Postavení ČSSR ve světové ekonomice v období osmdesátých let. Praha: Ekonomický ústav ČSAV.

Zhang, B. (1997). Total factor productivity of grain production in the former Soviet Union. Journal of Comparative Economics, April 1997, 24(2), 202-209.

Zhu, X. (2012). Understanding China's growth: Past, present, and future. The Journal of Economic Perspectives, October 2012, 26(4), 103-124. 